\title{
H
}

Page 1 of 2

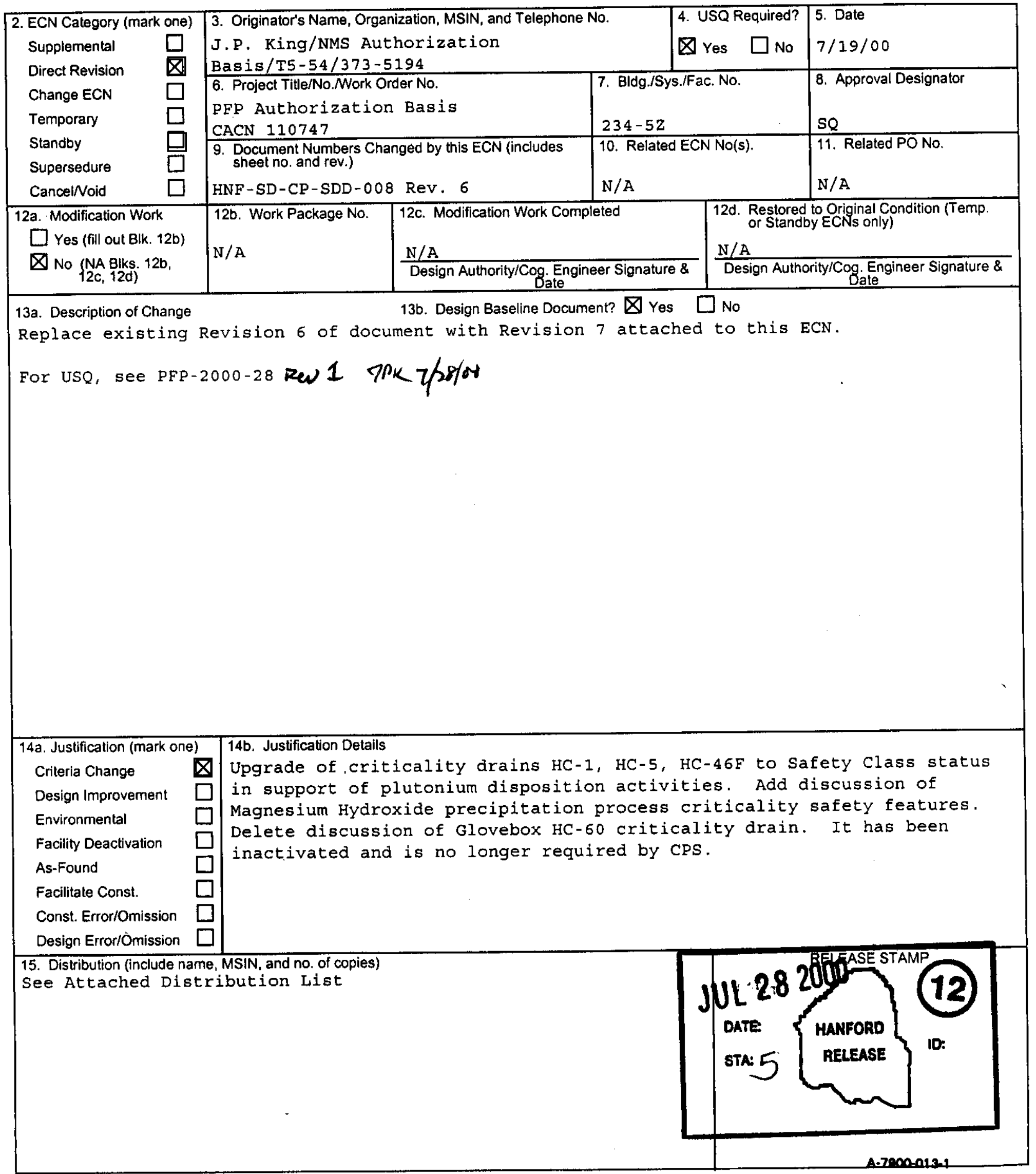




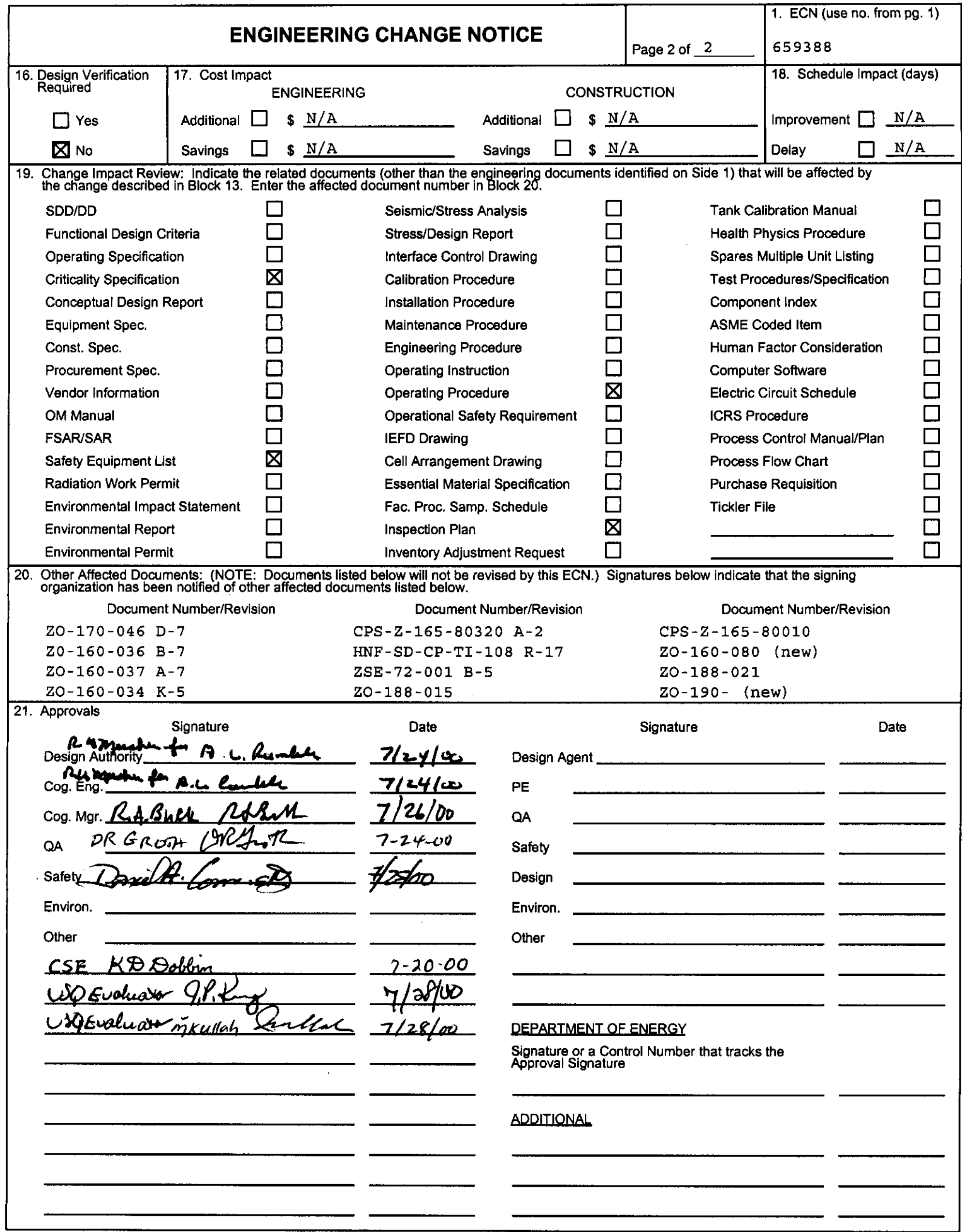




\section{Definition and Means of Maintaining the Criticality Prevention Design Features Portion of the PFP Safety Envelope}

Prepared for the U.S. Department of Energy

Assistant Secretary for Environmental Management

Project Hanford Management Contractor for the

U.S. Department of Energy under Contract DE-AC06-96RL 13200

Fluor Hanford

P.O. Box 1000

Richland, Washington 


\title{
Definition and Means of Maintaining the Criticality Prevention Design Features Portion of the PFP Safety Envelope
}

Project $\mathrm{No}: \mathrm{Mg}(\mathrm{OH}) 2$

Document Type: SDD

Division: NMS

\author{
A. L. Ramble \\ Fluor Hanford
}

Date Published

July 2000

Prepared for the U.S. Department of Energy Assistant Secretary for Environmental Management

Project Hanford Management Contractor for the

U.S. Department of Energy under Contract DE-AC06-96RL13200

\section{Fluor Hanford}

P.o. Box 1000

Richland, Washington
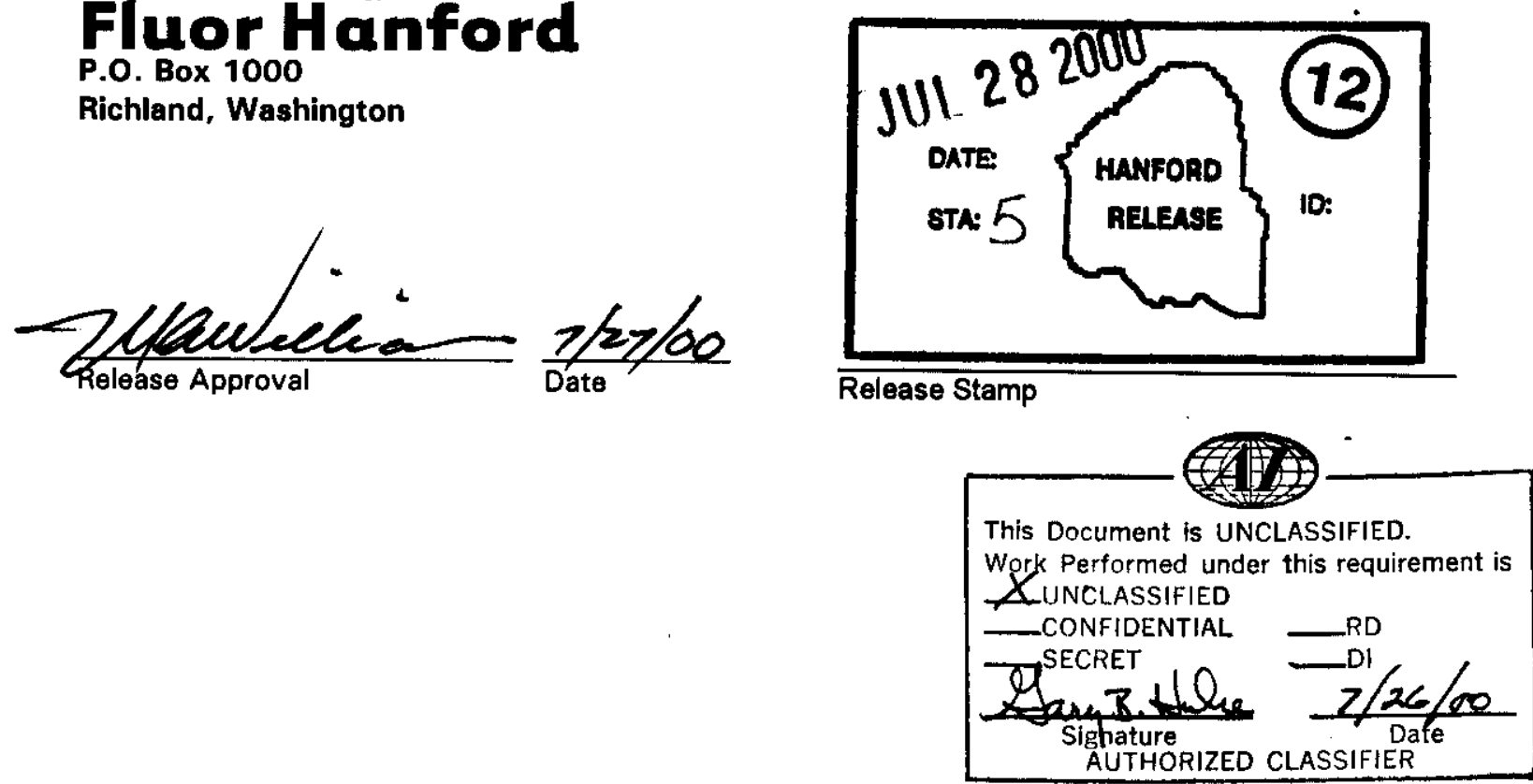


\section{LEGAL DISCLAIMER}

This report was prepared as an account of work sponsored by an agency of the United States Government. Neither the United States Government nor any agency thereof, nor any of their employees, nor any of their contractors, subcontractors or their employees, makes any warranty, express or implied, or assumes any legal liability or responsibility for the accuracy, completeness, or any third party's use or the results of such use of any information, apparatus, product, or process disclosed, or represents that its use would not infringe privately owned rights. Reference herein to any specific commercial product, process, or service by trade name, trademark, manufacturer, or othenwise, does not necessarily constitute or imply its endorsement, recommendation, or favoring by the United States Government or any agency thereof or its contractors or subcontractors. The views and opinions of authors expressed herein do not necessarily state or reflect those of the United States Government or any agency thereof.

This report has been reproduced from the best available copy.

Printed in the United States of America

Total Pages 23 
Rev. 7

(1) Document Number

HNF-SD-CP-SDD-008
Page 1

(2) Title

DEFINITION AND MEANS OF MAINTAINING THE CRITICALITY PREVENTION DESIGN FEATURES PORTION OF THE PFP SAFETY ENVELOPE

CHANGE CONTROL RECORD

\begin{tabular}{|c|c|c|c|}
\hline \multirow[t]{2}{*}{ (3) Revision } & \multirow{2}{*}{$\begin{array}{l}\text { (4) Description of Change - Replace, Add, and } \\
\text { Delete Pages }\end{array}$} & \multicolumn{2}{|c|}{ Authorized for Release } \\
\hline & & $\begin{array}{l}\text { (5) Cog. } \\
\text { Engr. }\end{array}$ & $\begin{array}{l}\text { (6) Cog. } \\
\text { Mgr. }\end{array}$ \\
\hline 5 & $\begin{array}{l}\text { Incorporate SEL HNF-SD-CP-TI-108 changes. } \\
\text { Incorporate ECN } 649627 \text {. ECN } 653592\end{array}$ & AL Ramble & PE Roege \\
\hline $5 \mathrm{~A}$ & Change page 4 per ECN 654876 & AL Ramble & PE Roege \\
\hline 6 & Replaces Rev. 5, 5A in its entirety. ECN 657608 & AL Ramble & PE Roege \\
\hline RE 7 & Replaces Rev. 6 in its entirety. ECN 659388 & $\frac{\text { AL Ramble }}{\text { elam }}$ & 2017/26/00 \\
\hline & & & \\
\hline & & & \\
\hline & & & \\
\hline & & & \\
\hline & & & \\
\hline & & & \\
\hline & & & \\
\hline & & & \\
\hline & & & \\
\hline
\end{tabular}




\section{TABLE OF CONTENTS}

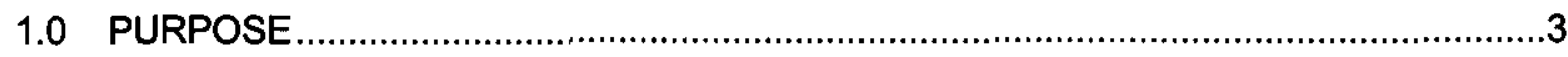

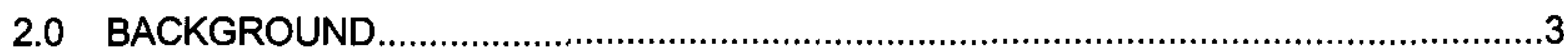

3.0 SYSTEM FUNCTIONAL REQUIREMENTS ....................................................4

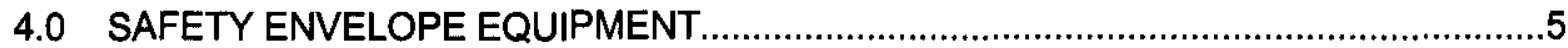

4.1 26-INCH HG PROCESS VACUUM SYSTEM AUTOMATIC SHUTDOWN AND ISOLATION FEATURES (CSER 78-013 AND CPS 80141) ...................................5

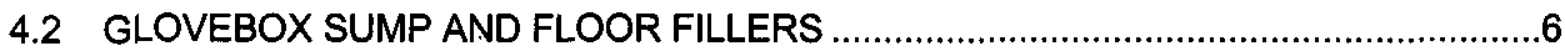

4.2.1 Glovebox HC-7, Room 228-A (CSARs 79-024, 87-005, 88-001, 90-009, and CPS 80607) ............................................................................ 6

4.2.2 Glovebox HC-9B, Room 228A (CSARs 79-019 and 87-005, and CPS 80609). 4 5

4.3 Glovebox HC-6, Room 166 (CSAR 79-018 and 79-022 and CPS 80606)

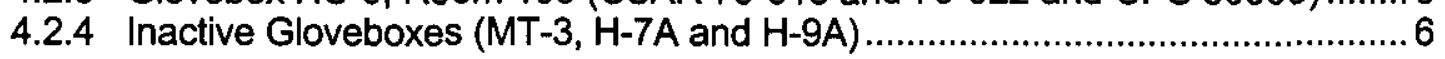

4.3 RASCHIG RINGS IN GLOVEBOX HC-6, OVERFLOW TANK SYSTEM (CSER 79-018 AND 79-022 AND CPS 80606) .7

4.4 CRITICALITY DRAINS (CSAR and CPS listed in Appendix B) .................................

4.5 OTHER CRITICALITY SAFETY FEATURES NOT SUBJECT TO LCO LEVEL CONTROL

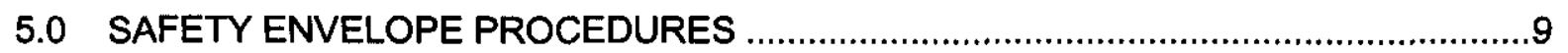

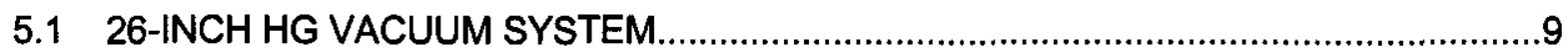

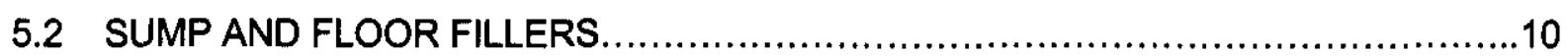

5.3 RASCHIG RINGS-GLOVEBOX HC-6 OVERFLOW TANK SYSTEM, ROOM $166 \ldots . . . . .10$

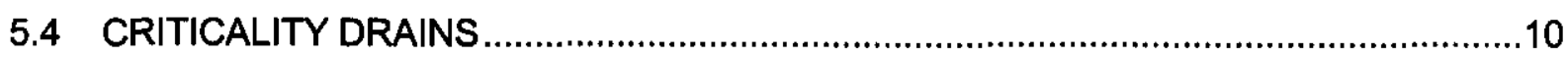

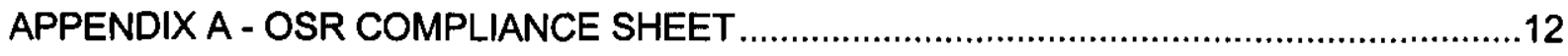

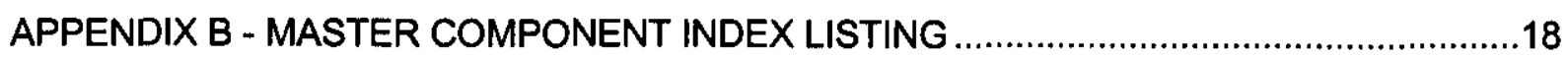




\subsection{PURPOSE}

The purpose of this document is to record the technical evaluation of the Operational Safety Requirements described in the Plutonium Finishing Plant Final (PFP) Operational Safety Requirements, WHC-SD-CP-OSR-010, Rev. 0-N, Section 3.1.1, "Criticality Prevention System." This document, with its appendices, provides the following:

1. The results of a review of Criticality Safety Analysis Reports (CSAR), later called Criticality Safety Evaluation Reports (CSER), and Criticality Prevention Specifications (CPS) to determine which equipment or components analyzed in the CSER or CPS are considered as one of the two unlikely, independent, and concurrent changes before a criticality accident is possible.

2. Evaluations of equipment or components to determine the safety boundary for the system (Section 4).

3. A list of essential drawings that show the safety system or component (Appendix A).

4. A list of the safety envelope (SE) equipment (Appendix B).

5. Functional requirements for the individual safety envelope equipment (Sections 3 and 4).

6. A list of the operational and surveillance procedures necessary to maintain the system equipment within the safety envelope (Section 5 ).

\subsection{BACKGROUND}

The Criticality Safety Evaluation Reports (CSER) and associated Criticality Prevention Specifications (CPS) were reviewed to determine if an equipment or system failure considered in the analysis as one of the two unlikely, independent, and concurrent changes required before a criticality accident is possible had been included in specifications, procedures, and surveillance.

The CSERs take into consideration and use various factors as error or failure parameters. These include:

\footnotetext{
- Geometrically favorable equipment,

- Maximum fissile masses,

- Moderation control,

- Maximum single container volume and mass,

- Maximum total volume and mass,

- Minimum spacing between containers,

- Maximum glovebox solids accumulation,

- Criticality drains,

- Maximum solids in tanks,

- $\quad$ Plutonium solution pH to control polymerization,

- Expeditious spill cleanup, and
} 
- $\quad$ Fissile material content of glovebox gloves.

The parameters are addressed in each CSER to assure that after one failure/error contingency the system will remain subcritical. These parameters and the calculations that establish their CPS limits were not inspected during this review. The review was concerned only with the identification of any specified physical or mechanical item evaluated as one of the two allowed events or contingencies and that the item identified was properly included in essential design drawings, the CSER, the CPS, and surveillance procedures.

\subsection{SYSTEM FUNCTIONAL REQUIREMENTS}

The Limiting Condition of Operation (LCO) requirements for the Criticality Prevention System are:

3.1 The 26-Inch Process Vacuum Liquid Detection Interlock System shall be OPERABLE whenever the 26-Inch Process Vacuum System is operating.

3.2 Glovebox Criticality Drains shall be OPERABLE (unobstructed) in the following locations:

234-5Z Gloveboxes

$\begin{array}{ll}\text { HC-1 } & H C-227 T \\ H C-4 & H C-227 S \\ H C-5 & H A-211 \\ H C-6 & H A-23 S \\ H C-7 & \underline{H C-230 C-3} \\ \text { HC-9B } & \underline{H C-230 C-4} \\ & \underline{H C-46 F}\end{array}$

Pu Process Support Laboratories Gloveboxes

188-1

$179-10$

$179-12$

Engineering Laboratory Glovebox

522 (Room 152)

236-Z Gloveboxes

MT-5

MT-6

4th Floor Column

1st Floor East Cell Access

5th Floor Column (pipe chase)

1st Floor West Cell Access

6th Floor Column (pipe chase)

2nd Floor East Cell Access

2nd Floor West Cell Access 
3.3 The following criticality safety features shall be in place.

- Glovebox Sump Discs in gloveboxes HC-7, HC-9B

- $\quad$ Glovebox Floor Filler Plates in glovebox HC-6

- Raschig Rings in Room 166 Sump

Compliance with the requirements in the LCO, CPS and CSER are ensured by monthly inspections of the plant, equipment and criticality prevention postings; performance of functional tests; and compliance with procedural requirements. If the LCO, CPS or CSER requirements are not met, affected fissionable materials operations are immediately halted, specified notifications made, and a recovery plan is prepared and approved.

\subsection{SAFETY ENVELOPE EQUIPMENT}

Based on the review performed, there are several specific physical components or systems that must be present and/or operable to prevent criticality after the occurrence of a failure contingency. These are:

- $\quad$ Automatic shutdown and isolation features of the 26-inch Hg Process Vacuum System,

- Glovebox sump discs or floor filler plates used to limit glovebox solution depths before overflow,

- $\quad$ The Raschig rings used in the HC-6 overflow tank system in Room 166

- Glovebox criticality drains

Since these systems and component are considered to be present to prevent a criticality, they are Safety Class items in accordance with HNF-PRO-704. CSER evaluations have assumed that these items are present and operable. A more detailed description of these items is presented below.

\subsection{6-INCH HG PROCESS VACUUM SYSTEM AUTOMATIC SHUTDOWN AND ISOLATION FEATURES (CSER 78-013 AND CPS 80141)}

Accidental criticality could occur in the 26-inch process vacuum HEPA filters if a solution containing plutonium were to enter the HEPA filterbox.

The possibility of accidental criticality is reduced by providing one engineered contingency (26-inch process vacuum interlock system) and administrative controls (PFP Operating Procedures) governing the use of the vacuum system for liquid transfers.

Further details on the 26-inch $\mathrm{Hg}$ Process Vacuum System, including procedures and surveillance, are provided in HNF-SD-CP-SDD-013, Definition and Means of Maintaining the Process Vacuum Liquid Detection Interlock Systems Portion of the PFP Safety Envelope. 


\subsection{GLOVEBOX SUMP AND FLOOR FILLERS}

Glovebox sump and floor fillers have been installed to limit the solution depth to the criticality drain overflows and to fill 11 -inch diameter by 2 -inch deep sumps. These are Safety Class items.

4.2.1 Glovebox HC-7, Room 228-A (CSARs 79-024, 87-005, 88-001, 90-009, and CPS 80607)

The initial CSER 79-024 evaluation and a subsequent reevaluation, CSER 87-005, assumed that an 11-inch diameter, 2-inch thick stainless steel disc would be in place to fill the floor sump in glovebox HC-7. The sump filler disc is located by $\mathrm{H}-2-93504-3$, EFD, RMC Line and described in $\mathrm{H}-2-24640$ Sheets 1 and 2, Sump Probes for Gloveboxes. The disc's presence is verified by procedure ZSE72-001, Perform Monthly Criticality Drain Inspection that requires a visual check that the disc is in place. If and when the glovebox is reactivated, a supplemental check of the sump filler disk check will be added to a more frequently performed procedure.

\subsubsection{Glovebox HC-9B, Room 228A (CSARs 79-019 and 87-005, and CPS 80609)}

A sump disc as described for $\mathrm{HC}-7$ above is also required in $\mathrm{HC}-9 \mathrm{~B}$ by the CPS. The disc is located by H-2-93504-3, EFD, RMC Line and described in drawing $\mathrm{H}-2-24640$ Sheets 1 and 2 . The verification surveillance is the same as for the HC-7 disc above.

\subsubsection{Glovebox HC-6, Room 166 (CSAR 79-018 and 79-022 and CPS 80606)}

Plates on glovebox HC-6 floor (1-1/2-inch + 1/4-inch thick Lexan ${ }^{1}$ and stainless steel) are required by the CPS to maintain a safe slab in event of leakage. CPS 80606 and CSER 79-022 specify the plates. Drawing H-2-19405, ECN 500050 shows the plates location.

\subsubsection{Inactive Gloveboxes (MT-3, H-7A and H-9A)}

The CSER's for these gloveboxes require steel sump discs in the bottom to prevent exceeding a safe slab thickness before overflow to the criticality drain. All of these gloveboxes are out of service and respective CPSs are no longer needed. The gloveboxes are posted to prevent the addition, movement, storage, or removal of materials. New CSERs and CPS will be required to do any of the above or to start processing in MT-3, H-7A or H-9A.

If any of these gloveboxes are returned to service the sump fillers shall become Safety Class equipment and shall be added to the Safety Equipment List based upon the new CSER and CPS.

'Lexan is a trademark of General Electric Co. 


\subsection{RASCHIG RINGS IN GLOVEBOX HC-6, OVERFLOW TANK SYSTEM (CSER 79-018 AND 79-022 AND CPS 80606)}

The CSER and CPS require the two HC-6 overflow tank floor pits in Room 166 near $\mathrm{HC}-6$ be filled with Raschig rings to prevent criticality in case of box overflow through the criticality drains in Room 166. Drawing H-2-25598 specifies the rings. All calculations in the CSERs assumed the rings to be present. The HC- 6 storage tanks are blanked off and are not presently in use but solution transfers are made through this box. The HC-4 Glovebox criticality drain is also located near the floor pits.

The ANSI/ANS Standard 8.5-1986, Use of Borosilicate Glass Raschig Rings as a Neutron Absorber in Solutions of Fissile Material, requires confirmation that no liquids have been present prior to a biennial settling examination when the rings are used as secondary control. Secondary control applies when the rings are not in contact with solutions where solids buildup, ring corrosion, and ring damage from solution agitation is not possible. The rings have been physically measured and standard tests for the specifications of glass density, boron and boron-10 content and chemical corrosion resistance have been conducted in accordance with the standard.

\subsection{CRITICALITY DRAINS (CSAR and CPS listed in Appendix B)}

Criticality drains are provided for gloveboxes throughout 234-5Z, including the Plutonium Process Support Laboratory and the Analytical Laboratory, and in building $236-Z$. The CSER's for many of these the gloveboxes assume the criticality drains are present, free flowing and not plugged. If the criticality drains were plugged, gloveboxes with sufficient fissile material could become critical with one additional contingency. For this reason, the criticality drains in the gloveboxes listed below are included in the safety envelope and are Safety Class equipment:

\section{4-5Z Gloveboxes}

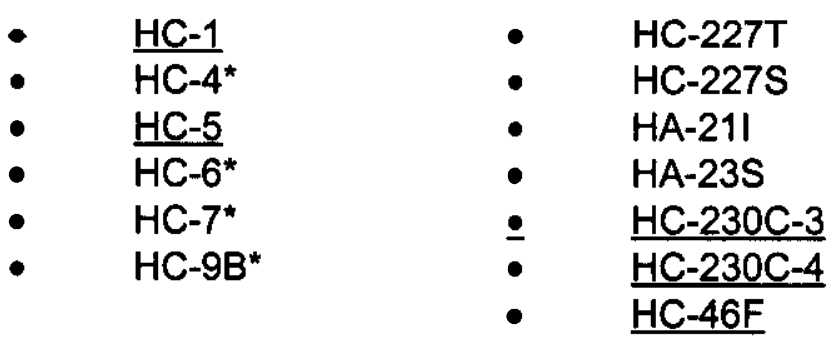

Pu Process Support Laboratorles Gloveboxes

188-1

$179-10$

$179-12$

Analytical Laboratory Glovebox 


\section{6-Z Gloveboxes}

$\begin{array}{llll}- & 4^{T H} \text { Floor Column } & \bullet & 1^{\text {ST }} \text { Floor East Cell Access } \\ \text { - } & 5^{\text {TH }} \text { Floor Column } & \bullet & 1^{\text {ST }} \text { Floor West Cell Access } \\ \text { - } & 6^{\text {TH }} \text { Floor Column } & \bullet & 2^{\text {ND }} \text { Floor East Cell Access } \\ \text { - } & \text { MT-5 } & \bullet & 2^{\text {ND }} \text { Floor West Cell Access } \\ \text { - } & \text { MT-6 } & & \end{array}$

Gloveboxes marked with an asterisk $\left(^{\star}\right)$ are equipped with sump alarms at approximately $1 / 2$-inch above the floor level to alert the operators before the criticality drain overflow is reached. These sump alarms do not perform safety function, however these sump alarms are tested before liquid transfers and periodically when solutions are present under PM $2 Z 22134$.

The MT-5 and MT- 6 gloveboxes are connected to the PRF process portion of the PFP closed loop cooling system. The MT processes are currently inactive and have no future use scheduled. Should future plans require the use of the process features, technical documents will be revised and re-issued.

Several gloveboxes with criticality drains are out of service and posted to prevent the addition, movement, storage or removal of material. CPS-Z-165-80010 establishes that if Hfany of the gloveboxes listed below are returned to service, their criticality drain(s) shall become Safety Class equipment and shall be added to the Safety Equipment List unless additional CSER $\underline{\underline{s}}$ are prepared to prove the criticality drains are not required.

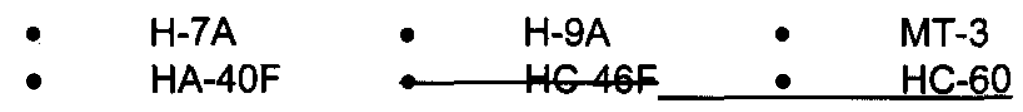

Due to operational changes over time, alterations to Gloveboxes $\mathrm{HC}-21 \mathrm{~A}$ and $\mathrm{HC}-21 \mathrm{C}$ have resulted in depressions below floor level which have some potential to accumulate fissile materials or wastes. Like other gloveboxes connected indirectly to the criticality drains in $\mathrm{HC}-1$ and $\mathrm{HC}-5$, gloveboxes $\mathrm{HC}$ $21 \mathrm{~A}$ and $\mathrm{HC}-21 \mathrm{C}$ handle only dry materials. Glovebox structure and exclusion of piping inside the gloveboxes preclude liquid entry under normal and most abnormal conditions. Material mass limits are used to ensure all areas in the gloveboxes would remain sub-critical even if fully moderated materials should accumulate. Filler blocks are in place in $\mathrm{HC}-21 \mathrm{~A}$ to ensure liquids entering the depression drain to the $\mathrm{HC}-2$ conveyor without exceeding volume limits. An isolation plate installed in $\mathrm{HC}-21 \mathrm{C}$ ensures that normal process materials cannot enter the depression in that glovebox. The blocks and plate are categorized as Safety Significant equipment; they are part of defense-in-depth provided by numerous criticality prevention limits and controls. 


\begin{abstract}
The critisality drain in Glovobox $+46-60$ is also included in the safoty envelope as Safety Significant oquipment. Buto tostriotions on the amount of plutonimm

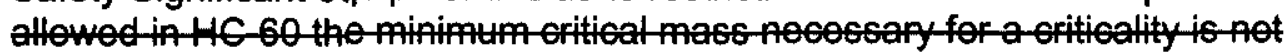
centaine in HG-60; therefore, failture to maintain riticality train operability is not considered to be ono of the oriticality sentingeneies for this Glovebox.
\end{abstract}

\title{
OTHER CRITICALITY SAFETY FEATURES NOT SUBJECT TO LCO LEVEL CONTROL
}

The LCO 3.1.1 Bases Background establishes that the LCO is applicable to "active" criticality safety features (i.e. those that could readily be misconfigured during routine plant operations or by component failure). Numerous criticality safety analysis or criticality safety evaluation reports (CSARs and CSERs) credit "passive" criticality safety features such as seismic qualification of gloveboxes or spacing/geometry of tanks or vessels for preventing a criticality contingency. Control of "passive" criticality safety features is provided by OSR Administrative Controls (ACs) 5.10 . "Facility Change Control", 5.11. "Unreviewed Safety Questions", and 5.15. "Nuclear Criticality Safety".

The CSERs for the magnesium hydroxide precipitation process utilize passive engineered features that provide geometrically favorable fissile material distributions within Gloveboxes $\mathrm{HC}-230 \mathrm{C}-3$ and $\mathrm{HC}-230 \mathrm{C}-4$. These criticality design features are Safety Class because they are relied upon to maintain double contingency protection against an accidental nuclear criticality. In particular, for Gloveboxes HC-230C-3 and $\mathrm{HC}-230 \mathrm{C}-4$, the external structural framework (including floor anchors), precipitator tank and filtrate tank inner diameters, inner heights, intra-tank spacing, and filter basin diameter and height both above and below the filter plate, as well as criticality drains are identified. The engineering drawings for these gloveboxes and details are included in the the SDD Appendix A OSR Compliance Sheet for completeness.

\subsection{SAFETY ENVELOPE PROCEDURES}

Safety envelope (ZSE) procedures provide administrative control over the operation, maintenance, and surveillance of process equipment to maintain the operability of safety envelope components. ZSE procedures also provide for proper response to alarms resulting from abnormal conditions and/or equipment failures. In addition, the procedures identified below satisfy criticality prevention specifications and provide operators with instructions and precautions related to the presence and operation of the criticality prevention design features identified in this document.

\section{$5.126-I N C H$ HG VACUUM SYSTEM}

Operation, maintenance and surveillance procedures which satisfy CPS-Z-165-80141 (26-Inch $\mathrm{Hg}$ Vacuum System) are provided in Definition and Means of Maintaining the Process Vacuum Liquid Detection Interlock Systems Portion of the PFP Safety Envelope, HNF-SD-CP-SDD-013. 


\subsection{SUMP AND FLOOR FILLERS}

Procedure 20-100-400, Perform Nuclear Operations Surveillance and Responses are performed on regularly scheduled workdays. During procedure performance visual inspections of gloveboxes are made which would detect an obviously off-standard condition which would include missing sump or floor fillers in gloveboxes HC-6, HC-7 and HC-9B. This satisfies CPS-Z-165-80607, Glovebox HC-7: Feed Preparation; CPS-Z-165-80609, Glovebox HC-9B: Continuous Nitrate to Oxide Conversion; and CPS-Z-165-80606, Glovebox HC-6: Solution Transfer. If and when glovebox processes are reactivated, more detailed supplemental checks of sump and floor fillers will be added to procedures that are performed more frequently than the ZSE inspections.

Surveillance Requirement 3.1.1.3.1 is satisfied by performing ZSE-72-001, Perform Monthly Criticality Drain Inspection.

\subsection{RASCHIG RINGS-GLOVEBOX HC-6 OVERFLOW TANK SYSTEM, ROOM 166}

Surveillance Requirement 3.1.1.3.1 is satisfied by performing ZSE-72-001, Perform Monthly Criticality Drain Inspection.

\subsection{CRITICALITY DRAINS}

Procedure ZO-100-400, Perform Nuclear Operations Surveillance and Responses are performed on regularly scheduled workdays. During procedure performance visual inspections of gloveboxes are made which would detect an obviously off-standard condition which would include solutions in excess of criticality prevention specification limits discovered standing in glovebox bays or on floors indicating a restricted criticality drain. This satisfies CPS-Z-165-80010, General Limits, and CPS-L-114-00010, Laboratory Uniform General Limits. If and when glovebox processes are reactivated, more detailed supplemental checks of criticality drains will be added to procedures that are performed more frequently than the ZSE inspections.

Procedure ZO-180-040, Test MT Criticality Drains, performs a monthly flow check of the MT-5 and MT-6 criticality drains to verify the drains are free flowing and not plugged. This procedure does not have to be performed to satisfy SR 3.1.1.2.1. It is an optional procedure performed to comply with good engineering practice and may not be performed when the MT- 5 and MT- 6 gloveboxes are not being used for processing.

Plant Operating Procedures for gloveboxes with criticality drains include criticality safety cautions concerning criticality drain operability and/or water flow limitations into the glovebox. The complete list of these procedures is provided as Attachment 1 of Appendix A.

Surveillance Requirement 3.1.1.2.1 is satisfied by performing ZSE-72-001, Perform Monthly Criticality Drain Inspection. 


\subsection{REFERENCES}

1. HNF-SD-CP-SAR-021, Plutonium Finishing Plant Final Safety Analysis Report (PFP FSAR), Rev. 1.

2. WHC-SD-CP-OSR-010, Plutonium Finishing Plant Operational Safety Requirements, Rev. 0-N.

3. WHC-SD-C084-RA-001, PFP Seismic Upgrades Review.

4. HNF-PRO-704, Hazard and Accident Analysis Process, Rev 0.

5. HNF-SD-CP-SDD-013, Rev. 3, Definition and Means of Maintaining the Process Vacuum Liquid Detection Interlock Systems Portion of the PFP Safety Envelope.

6. ANSI/ANS Standard 8.5-1986, Use of Borosilicate Glass Raschig Rings as a Neutron Absorber in Solutions of Fissile Material. 


\section{APPENDIX A - OSR COMPLIANCE SHEET}

\section{OSR LCO COMPLIANCE SHEET}

\section{APPLICABLE OSR LCO (WHC-SD-CP-OSR-010, Rev. 0, Section 3.0):}

\subsubsection{Criticality Prevention System}

LCO 3.1.1.1 . The 26-Inch Process Vacuum Liquid Detection Interlock System shall be OPERABLE whenever the 26-Inch Process Vacuum System is operating

LCO 3.1.1.2 Glovebox Criticality Drains shall be OPERABLE (Unobstructed) in the following locations:

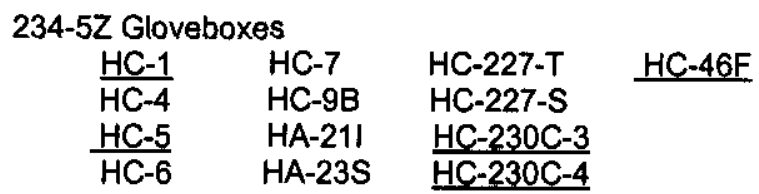

Pu Process Support Laboratories Gloveboxes

188-1

$179-10$

179-12

Analytical Laboratory Glovebox

522 (Room 152)

236-Z Gloveboxes

MT-5

MT-6

4th Floor Column

5 th Floor Column

1st Floor East Cell Access

1st Floor West Cell Access

6th Floor Column

2nd Floor East Cell Access

2nd Floor West Cell Access

LCO 3.1.1.3 The following criticality safety features shall be in place:

Glovebox Sump Discs in gloveboxes HC-7, HC-9B

Glovebox Floor Filler Plates in glovebox HC-6

Raschig Rings in Room 166 Sump

APPLICABILITY: 3.1.1.1 All MODES

3.1.1.2 All MODES

3.1.1.3 All MODES 


\begin{tabular}{|c|c|c|c|c|}
\hline \multicolumn{5}{|c|}{ OSR LCO COMPLIANCE SHEET } \\
\hline \multicolumn{5}{|c|}{$\begin{array}{l}\text { APPLICABLE OSR LCO (WHC-SD-CP-OSR-010, Rev. 0, Section 3.0): } \\
3.1 .1 \text { Critlcality Prevention Systiom }\end{array}$} \\
\hline \multicolumn{5}{|c|}{ ACTIONS: } \\
\hline & CONDITION & & REQUIRED ACTION & COMPLETION TIME \\
\hline & $\begin{array}{l}\text { Process Vacuum Liquid Detection } \\
\text { Interlock System is inoperable. }\end{array}$ & $\begin{array}{l}\text { A.1 } \\
\text { AND } \\
\text { A.2 }\end{array}$ & $\begin{array}{l}\text { Shut down } 26-\text { Inch Process } \\
\text { Vacuum System. } \\
\text { Enter MODE 2, Limited Plutonium } \\
\text { Handling Operations. Prohibit all } \\
\text { liquid transfers using 26" vacuum } \\
\text { system. }\end{array}$ & $\begin{array}{l}\text { IMMEDIATELY } \\
\text { IMMEDIATELY }\end{array}$ \\
\hline & Criticality Drain is inoperable. & $\begin{array}{l}\text { B.1 } \\
\text { AND } \\
\text { If a cr } \\
\text { obstry } \\
\text { cleare } \\
\text { the dr } \\
\text { place } \\
\text { shift } r \\
\text { IMME } \\
\text { cleare } \\
\text { instar } \\
\text { B.2 st } \\
\text { enter } \\
\text { docur }\end{array}$ & 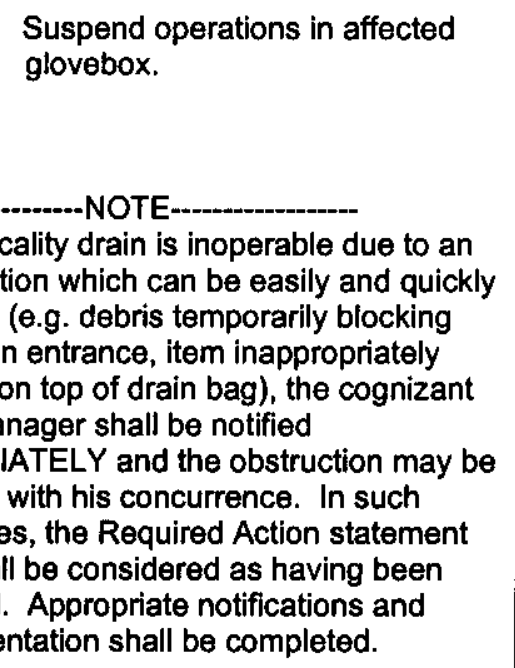 & IMMEDIATELY \\
\hline & & B.2 & $\begin{array}{l}\text { Restore Criticality Drain to } \\
\text { OPERABLE condition in } \\
\text { accordance with a RECOVERY } \\
\text { PLAN. }\end{array}$ & IMMEDIATELY \\
\hline & $\begin{array}{l}\text { Criticality safety feature required by LCO } \\
3.1 .1 .3 \text { is not present. }\end{array}$ & $\begin{array}{l}\text { C.1 } \\
\frac{\text { AND }}{C .2}\end{array}$ & $\begin{array}{l}\text { Suspend operations in affected } \\
\text { glovebox(es). } \\
\text { Restore criticality safety features } \\
\text { in accordance with a RECOVERY } \\
\text { PLAN. }\end{array}$ & $\begin{array}{l}\text { IMMEDIATELY } \\
\text { IMMEDIATELY }\end{array}$ \\
\hline
\end{tabular}


OSR LCO COMPLIANCE SHEET

APPLICABLE OSR LCO (WHC-SD-CP-OSR-010, Rev. 0, Section 3.0):

3.1.1 Criticality Prevention System

\begin{tabular}{|c|c|c|}
\hline . & SURVEILLANCE & FREQUENCY \\
\hline SR 3.1.1.1.1 & $\begin{array}{l}\text { VERIFY OPERABILITY of the Process Vacuum Liquid Detection } \\
\text { Interlock System supervisory circuit. }\end{array}$ & $\begin{array}{l}\text { Once within } 24 \text { hours } \\
\text { prior to startup of the } \\
26 \text {-Inch Process } \\
\text { Vacuum System } \\
\text { AND } \\
\text { Daily thereafter while } \\
\text { the 26-Inch Process } \\
\text { Vacuum System is } \\
\text { operating }\end{array}$ \\
\hline SR 3.1.1.1.2 & $\begin{array}{l}\text { Perform a FUNCTIONAL TEST of the Process Vacuum Liquid } \\
\text { Detection Interlock System. }\end{array}$ & Semi-annually \\
\hline SR 3.1.1.2.1 & VERIFY OPERABILITY of the Criticality Drains. & Monthly \\
\hline SR 3.1.1.3.1 & $\begin{array}{l}\text { VERIFY presence of the criticality safety features required by LCO } \\
\text { 3.1.1.3. }\end{array}$ & Monthly \\
\hline
\end{tabular}

APPLICABLE ACCIDENT ANALYSES FSAR (HNF-SD-CP-SAR-021, CH 9) SECTION/TITLE:

9.2 ACCIDENTS

9.2.3 Criticality

APPLICABLE PLANT/PROCESS DESIGN/OPERATION DESCRIPTION(S) [FSAR CHAPTER/ SECTION]:

4.0 PRINCIPAL DESIGN CRITERIA

4.3 SAFETY PROTECTION SYSTEMS

4.3.4 Nuclear Criticality Design Criteria 
APPLICABLE OSR LCO (WHC-SD-CP-OSR-010, Rev. 0, Section 3.0):

3.1.1 Criticality Prevention System

BOUNDARY IDENTIFICATION DRAWINGS

EXPORT CONTROLLED INFORMATION SEE DOCUMENT AUTHOR FOR DRAWING LISTING 


\section{OSR LCO COMPLIANCE SHEET}

APPLICABLE OSR LCO (WHC-SD-CP-OSR-010, Rev. 0, Section 3.0):

3.1.1 Criticality Prevention System

ESSENTIAL SYSTEM DRAWINGS

EXPORT CONTROLLED INFORMATION SEE DOCUMENT AUTHOR FOR DRAWING LISTING 


\section{OSR LCO COMPLIANCE SHEET}

APPLICABLE OSR LCO (WHC-SD-CP-OSR-010, Rev. 0, Section 3.0):

\subsubsection{Criticality Prevention Systiom}

IMPLEMENTING PROCE:DURES/COMPLIANCE VERIFICATION

\section{OPERATING [ZO-series]:}

ZO-100-400, Perform Nuclear Operations Surveillance and Responses

ZO-170-046, Change Criticality Drain Tubes

\section{LABORATORY [ZP-, LO-, LA- series]: ZP-100-009, Change PPSL Criticality Drain Tubes}

HEALTH PHYSICS [IP-0692 series]: NONE

\section{SUPPORTING DOCUMENTS:}

HNF-SD-CP-SDD-008, Definition and Means of Maintaining the Criticality Prevention Design Features Portion of the PFP

Safety Envelope

\section{ADMINISTRATIVE [FSP-PFP-5-8, etc]:}

FSP-PFP-5-8, PFP Administration Manual, Section 3.3 Criticality Safety.

MAINTENANCE [2Z-, 1-ZM-, etc]: NONE

\begin{tabular}{|l|l|l|l|}
\hline $\begin{array}{l}\text { SURVEILLANCE } \\
\text { REQUIREMENT }\end{array}$ & \multicolumn{1}{|c|}{$\begin{array}{c}\text { PROCEDURE } \\
\text { NUMBER }\end{array}$} & \multicolumn{1}{|c|}{ DESCRIPTION } & \multicolumn{1}{|c|}{$\begin{array}{c}\text { PROCEDURE } \\
\text { FREQUENCY }\end{array}$} \\
\hline SR 3.1.1.1.1 & $\begin{array}{l}\text { See HNF-SD-CP-SDD- } \\
013\end{array}$ & $26^{\prime \prime}$ Vacuum System Design Description & $\begin{array}{l}\text { Upon Demand and } \\
\text { Daily When } \\
\text { Operating }\end{array}$ \\
\hline SR 3.1.1.1.2 & $\begin{array}{l}\text { See HNF-SD-CP-SDD- } \\
013\end{array}$ & 26 " Vacuum System Design Description & Semi-Annual \\
\hline SR 3.1.1.2.1 & ZSE-72-001 & $\begin{array}{l}\text { Monthly Criticality Drain and Safety } \\
\text { Feature Inspection }\end{array}$ & Monthly \\
\hline SR 3.1.1.3.1 & ZSE-72-001 & $\begin{array}{l}\text { Monthly Criticality Drain and Safety } \\
\text { Feature Inspection }\end{array}$ & Monthly \\
\hline
\end{tabular}

OTHER: NONE

NOTES/COMMENTS: 


\section{APPENDIX B - MASTER COMPONENT INDEX LISTING}

\begin{tabular}{|c|c|c|c|}
\hline \multicolumn{4}{|c|}{$\begin{array}{l}\text { SE SYSTEMS COMPLIANCE SHEET } \\
\text { CRITICALITY DRAINS AND SCREENS, FILLER DISCS AND RASCHIG RINGS }\end{array}$} \\
\hline \multicolumn{4}{|c|}{$\begin{array}{l}\text { APPLICABLE OSR LCO (WHC-SD-CP-OSR-010 Section 3.0): } \\
3.1 .1 \text { Criticality Prevention System }\end{array}$} \\
\hline \multicolumn{4}{|c|}{ SE SYSTEM EQUIPMENT/COMPONENT LIST } \\
\hline $\begin{array}{l}\text { MASTER } \\
\text { COMPONENT } \\
\text { INDEX } \\
\text { NUMBER } \\
\end{array}$ & $\begin{array}{l}\text { FUNCTIONAL } \\
\text { DESCRIPTION }\end{array}$ & $\begin{array}{l}\text { CRITICALITY } \\
\text { PREVENTION } \\
\text { SPECIFICATION } \\
\text { NUMBER } \\
\end{array}$ & $\begin{array}{l}\text { ESSENTIAL } \\
\text { DRAWING NUMBER }\end{array}$ \\
\hline CRDR-1ST_EAST & $\begin{array}{l}236-Z \text { GLOVEBOX } 1 \text { st FLOOR EAST } \\
\text { CRITICALITY DRAIN AND SCREEN. } \\
\text { FOR ASSEMBLY, ARRANGEMENT, and } \\
\text { INSTALLATION SEE DRAWINGS } \\
\text { H-2-27145 and } \mathrm{H}-2-28822 \text {. }\end{array}$ & $\begin{array}{l}\text { CPS-Z-165-80707 } \\
\text { CPS-Z-165-80010 } \\
\text { CSAR-80-029 } \\
\text { CSAR-80-011, Add } 2\end{array}$ & $\begin{array}{l}\text { EXPORT } \\
\text { CONTROLLED } \\
\text { INFORMATION. }\end{array}$ \\
\hline CRDR-1ST_WEST & $\begin{array}{l}\text { 236-Z GLOVEBOX } 1 \text { st FLOOR WEST } \\
\text { CRITICALITY DRAIN AND SCREEN. } \\
\text { FOR ASSEMBLY, ARRANGEMENT, and } \\
\text { INSTALLATION SEE DRAWINGS } \\
\mathrm{H}-2-27145 \text { and } \mathrm{H}-2-28822 \text {. }\end{array}$ & $\begin{array}{l}\text { CPS-Z-165-80708 } \\
\text { CPS-Z-165-80010 } \\
\text { CSAR-80-029 } \\
\text { CSAR-80-011, Add } 2\end{array}$ & \multirow{6}{*}{$\begin{array}{l}\text { SEE } \\
\text { DOCUMENT } \\
\text { AUTHOR FOR } \\
\text { DRAWING } \\
\text { LISTING }\end{array}$} \\
\hline CRDR-HA-21I & $\begin{array}{l}\text { GLOVEBOX HA-21I CRITICALITY DRAIN } \\
\text { AND SCREEN. FOR ASSEMBLY, } \\
\text { ARRANGEMENT, and INSTALLATION } \\
\text { SEE DRAWING H-2-99537, AND H-2- } \\
27119\end{array}$ & $\begin{array}{l}\text { CPS-Z-165-80350 } \\
\text { CSER-99-007 }\end{array}$ & \\
\hline CRDR-HA-23S & $\begin{array}{l}\text { GLOVEBOX HA-23S CRITICALITY } \\
\text { DRAIN AND SCREEN. FOR ASSEMBLY, } \\
\text { ARRANGEMENT, and INSTALLATION } \\
\text { SEE DRAWINGS H-2-27135, H-2-28822, } \\
\text { and H-2-29010. }\end{array}$ & $\begin{array}{l}\text { CPS-Z-165-80090 } \\
\text { CPS-Z-165-80010 } \\
\text { CSAR-80-029 } \\
\text { CSER-91-007 }\end{array}$ & \\
\hline CRDR-HC-1 & $\begin{array}{l}\text { CONVEYOR GLOVEBOX HC-1 } \\
\text { CRITICALITY DRAIN AND SCREEN. } \\
\text { FOR ASSEMBLY, ARRANGEMENT, AND } \\
\text { INSTALLATION, SEE DRAWINGS H-2- } \\
\mathbf{2 7 1 3 5 , ~ H - 2 - 2 8 9 3 5 , ~ A N D ~ H - 2 - 2 7 1 1 9 ~}\end{array}$ & $\begin{array}{l}\text { CPS-Z-165-80010 } \\
\text { CPS-Z-165-80608 } \\
\text { CSER-00-008 }\end{array}$ & \\
\hline CRDR-HC-4 & $\begin{array}{l}\text { GLOVEBOX HC-4 CRITICALITY DRAIN } \\
\text { AND SCREEN. FOR ASSEMBLY, } \\
\text { ARRANGEMENT, and INSTALLLATION } \\
\text { SEE DRAWINGS H-2-27135,H-2-28B22, } \\
\text { AND H-2-27119. }\end{array}$ & $\begin{array}{l}\text { CPS-Z- } 165-80604 \\
\text { CPS-Z- } 165-80010 \\
\text { CSAR-80-029 } \\
\text { CSAR-79-020, Add } 1\end{array}$ & \\
\hline CRDR-HC-5 & $\begin{array}{l}\text { GLOVEBOX HC-5B CRITICALITY DRAIN } \\
\text { AND SCREEN. FOR ASSEMBLY, } \\
\text { ARRANGEMENT, AND INSTALLATION, } \\
\text { SEE DRAWINGS H-2-27135, H-2-28935, } \\
\text { AND H-2-27119 }\end{array}$ & $\begin{array}{l}\text { CPS-Z-165-80010 } \\
\text { CPS-Z-165-80170 } \\
\text { CSER-00-008 }\end{array}$ & \\
\hline
\end{tabular}




\begin{tabular}{|c|c|c|c|}
\hline \multicolumn{4}{|c|}{$\begin{array}{l}\text { SE SYSTEMS COMPLIANCE SHEET } \\
\text { CRITICALITY DRAINS AND SCREENS, FILLER DISCS AND RASCHIG RINGS }\end{array}$} \\
\hline \multicolumn{4}{|c|}{$\begin{array}{l}\text { APPLICABLE OSR LCO (WHC-SD-CP-OSR-010 Section 3.0): } \\
\text { 3.1.1 Criticality Prevention System }\end{array}$} \\
\hline \multicolumn{4}{|c|}{ SE SYSTEM EQUIPMENT/COMPONENT LIST } \\
\hline $\begin{array}{l}\text { MASTER } \\
\text { COMPONENT } \\
\text { INDEX } \\
\text { NUMBER }\end{array}$ & $\begin{array}{l}\text { FUNCTIONAL } \\
\text { DESCRIPTION }\end{array}$ & $\begin{array}{l}\text { CRITICALITY } \\
\text { PREVENTION } \\
\text { SPECIFICATION } \\
\text { NUMBER }\end{array}$ & $\begin{array}{l}\text { ESSENTIAL } \\
\text { DRAWING NUMBER }\end{array}$ \\
\hline CRDR-HC-6 & $\begin{array}{l}\text { GLOVEBOX HC-6 CRITICALITY DRAIN } \\
\text { AND SCREEN. FOR ASSEMBLY, } \\
\text { ARRANGEMENT, and INSTALLATION } \\
\text { SEE DRAWINGS H-2-27135 and } \\
\text { H-2-28822. }\end{array}$ & $\begin{array}{l}\text { CPS-Z-165-80606 } \\
\text { CPS-Z-165-80010 } \\
\text { CSAR-80-029 } \\
\text { CSAR-79-019, Add } 1 \\
\text { CSAR-79-022, Add } 1 / 2\end{array}$ & \\
\hline CRDR-HC-7 & $\begin{array}{l}\text { GLOVEBOX HC-7 CRITICALITY DRAIN } \\
\text { AND SCREEN. FOR ASSEMBLY, } \\
\text { ARRANGEMENT, and INSTALLATION } \\
\text { SEE DRAWINGS H-2-27135 and } \\
\text { H-2-28822. }\end{array}$ & $\begin{array}{l}\text { CPS-Z-165-80607 } \\
\text { CPS-Z-165-80010 } \\
\text { CSAR-80-029 } \\
\text { CSAR-79-024, Add } 1 \\
\text { CSAR-88-005 }\end{array}$ & \\
\hline CRDR-HC-9B & $\begin{array}{l}\text { GLOVEBOX HC-9B CRITICALITY DRAIN } \\
\text { AND SCREEN. FOR ASSEMBLY, } \\
\text { ARRANGEMENT and INSTALLATION } \\
\text { SEE DRAWINGS H-2-27135 and } \\
\text { H-2-28822. }\end{array}$ & $\begin{array}{l}\text { CPS-Z- } 165-80609 \\
\text { CPS-Z-165-80010 } \\
\text { CSAR-80-029 } \\
\text { CSAR-79-019, Add } 3\end{array}$ & \\
\hline CRDR-HC-46F & $\begin{array}{l}\text { GLOVEBOX HC-46F CRITICALITY } \\
\text { DRAIN AND SCREEN. FOR ASSEMBLY, } \\
\text { ARRANGEMENT AND INSTALLATION, } \\
\text { SEE ECN } 659352 \text { TO DRAWING H-2- } \\
27135 .\end{array}$ & $\begin{array}{l}\text { CPS-Z-165-80010 } \\
\text { CPS-Z-165-80320 } \\
\text { CSER-00-001 }\end{array}$ & \\
\hline CRDR-HC-227S & $\begin{array}{l}\text { GLOVEBOX HC-227S CRITICALITY } \\
\text { DRAIN AND SCREEN. FOR ASSEMBLY, } \\
\text { ARRANGEMENT, and INSTALLATION } \\
\text { SEE DRAWINGS H-2-27135 and } \\
\mathrm{H}-2-28822 \text {. }\end{array}$ & $\begin{array}{l}\text { CPS-Z-165-80623 } \\
\text { CPS-Z-165-80010 } \\
\text { CSAR-80-029 } \\
\text { CSAR-79-021, Add } 1 \\
\text { CSAR-88-005 } \\
\end{array}$ & \\
\hline CRDR-HC-227T & $\begin{array}{l}\text { HOOD HC-227T CRITICALITY DRAIN } \\
\text { AND SCREEN. FOR ASSEMBLY, } \\
\text { ARRANGEMENT, and INSTALLATION } \\
\text { SEE DRAWINGS H-2-27135 and } \\
\text { H-2-28822 and ECNs } 191519 \text {.and } \\
623378\end{array}$ & $\begin{array}{l}\text { CPS-Z-165-80601 } \\
\text { CPS-Z-165-80010 } \\
\text { CSAR-81-001, Add } 4\end{array}$ & \\
\hline CRDR-HC-230C-3C-3 & $\begin{array}{l}\text { MAGNESIUM HYDROXIDE GLOVEBOX } \\
3 \text { CRITICALITY DRAIN AND SCREEN. } \\
\text { FOR ASSEMBLY, ARRANGEMENT, AND } \\
\text { INSTALLATION, SEE DRAWING H-2- } \\
829782, \mathrm{H}-2-829784, \text { AND H-2-82993 }\end{array}$ & $\begin{array}{l}\text { CPS-Z-165-80642 } \\
\text { CSER } 00-003\end{array}$ & \\
\hline CRDR-HC-230C-4 & $\begin{array}{l}\text { MAGNESIUM HYDROXIDE GLOVEBOX } \\
4 \text { CRITICALITY DRAIN AND SCREEN. } \\
\text { FOR ASSEMBLY, ARRANGEMENT, AND } \\
\text { INSTALLATION, SEE DRAWING H-2- } \\
829783, \mathrm{H}-2-29785, \text { AND } \mathrm{H}-2-82993\end{array}$ & $\begin{array}{l}\text { CPS-Z-165-80643 } \\
\text { CSER-00-004 }\end{array}$ & \\
\hline
\end{tabular}




\begin{tabular}{|c|c|c|c|}
\hline \multicolumn{4}{|c|}{$\begin{array}{l}\text { SE SYSTEMS COMPLIANCE SHEET } \\
\text { CRITICALITY DRAINS AND SCREENS, FILLER DISCS AND RASCHIIG RINGS }\end{array}$} \\
\hline \multicolumn{4}{|c|}{$\begin{array}{l}\text { APPLICABLE OSR LCO (WHC-SD-CP-OSR-010 Section 3.0): } \\
\text { 3.1.1 Criticality Prevention System. }\end{array}$} \\
\hline \multicolumn{4}{|c|}{ SE SYSTEM EQUIPMENT/COMPONENT LIST } \\
\hline $\begin{array}{l}\text { MASTER } \\
\text { COMPONENT } \\
\text { INDEX } \\
\text { NUMBER }\end{array}$ & $\begin{array}{l}\text { FUNCTIONAL } \\
\text { DESCRIPTION }\end{array}$ & $\begin{array}{l}\text { CRITICALITY } \\
\text { PREVENTION } \\
\text { SPECIFICATION } \\
\text { NUMBER } \\
\end{array}$ & $\begin{array}{c}\text { ESSENTIAL } \\
\text { DRAWING NUMBER }\end{array}$ \\
\hline CRDR-MT-5 & $\begin{array}{l}\text { GLOVEBOX MT-5 CRITICALITY DRAIN } \\
\text { AND SCREEN. FOR ASSEMBLY, } \\
\text { ARRANGEMENT, and INSTALLATION } \\
\text { SEE DRAWINGS H-2-26865, H-2-28934 } \\
\text { and H-2-28935. }\end{array}$ & $\begin{array}{l}\text { CPS-Z-165-80715 } \\
\text { CPS-Z-165-80010 } \\
\text { CSAR-80-029 } \\
\text { CSAR-80-005 }\end{array}$ & \\
\hline CRDR-MT-6 & $\begin{array}{l}\text { GLOVEBOX MT-6 CRITICALITY DRAIN } \\
\text { AND SCREEN. FOR ASSEMBLY, } \\
\text { ARRANGEMENT, and INSTALLATION } \\
\text { SEE DRAWINGS H-2-26865, H-2-28934 } \\
\text { and H-2-28935. }\end{array}$ & $\begin{array}{l}\text { CPS-Z-165-80716 } \\
\text { CPS-Z-165-80010 } \\
\text { CSAR-80-029 } \\
\text { CSAR-78-006, Add } 1\end{array}$ & \\
\hline $\begin{array}{l}\text { GB-HC6- } \\
\text { SUMP_PLATE } \\
\text { GB-HC6- } \\
\text { RASCHIG_RINGS }\end{array}$ & $\begin{array}{l}\text { GLOVEBOX HC-6 FLOOR FILLER } \\
\text { PLATES AND PIT RASCHIG RINGS SEE } \\
\text { DRAWING H-2-25598 and CPS. }\end{array}$ & $\begin{array}{l}\text { CPS-Z-165-80606 } \\
\text { CSAR-79-018 } \\
\text { CSAR-79-022 }\end{array}$ & \\
\hline GB-HC7-SUMP_DISC & $\begin{array}{l}\text { GLOVEBOX HC-7 SUMP FILLER DISCS. } \\
\text { FOR ASSEMBLY AND INSTALLATION } \\
\text { SEE DRAWING H-2-24640 shts } 1 \& 2 .\end{array}$ & $\begin{array}{l}\text { CPS-Z-165-80607 } \\
\text { CSAR-79-024 } \\
\text { CSAR-87-005 } \\
\text { CSAR-88-001 } \\
\text { CSAR-90-009 }\end{array}$ & \\
\hline $\begin{array}{l}\text { GB-HC9B- } \\
\text { SUMP_DISC } \\
\end{array}$ & $\begin{array}{l}\text { GLOVEBOX HC-9B SUMP FILLER DISC. } \\
\text { FOR ASSEMBLY AND INSTALLATION } \\
\text { SEE DRAWING H-2-24640 shts } 1 \& 2 \text {. }\end{array}$ & $\begin{array}{l}\text { CPS-Z-165-80609 } \\
\text { CSAR-79-019 } \\
\text { CSAR-87-005 }\end{array}$ & \\
\hline $\begin{array}{l}\text { CRDR-2ND_WEST-1 } \\
\text { CRDR-2ND_WEST-2 } \\
\text { CRDR-2ND_WEST-3 } \\
\text { CRDR-2ND_WEST-4 } \\
\text { CRDR-2ND_WEST-5 } \\
\text { CRDR-2ND_WEST-6 } \\
\text { CRDR-2ND_WEST-7 } \\
\text { CRDR-2ND_WEST-8 } \\
\text { CRDR-2ND_WEST-9 } \\
\text { CRDR-2ND_WEST-10 } \\
\text { CRDR-2ND_WEST-11 }\end{array}$ & $\begin{array}{l}\text { CRITICALITY DRAIN 2ND WEST } \\
\text { GLOVEBOXES. FOR ASSEMBLY AND } \\
\text { INSTALLATION SEE DRAWING H-2- } \\
29941 \text { sht } 1 .\end{array}$ & $\begin{array}{l}\text { CPS-Z-165-80710 } \\
\text { CPS-Z-165-80010 } \\
\text { CSAR- } 80-029\end{array}$ & \\
\hline
\end{tabular}




\begin{tabular}{|c|c|c|c|}
\hline \multicolumn{4}{|c|}{$\begin{array}{l}\text { SE SYSTEMS COMPLIANCE SHEET } \\
\text { CRITICALITY DRAINS AND SCREENS, FILLER DISCS AND RASCHIG RINGS }\end{array}$} \\
\hline \multicolumn{4}{|c|}{$\begin{array}{l}\text { APPLICABLE OSR LCO (WHC-SD-CP-OSR-010 Section 3.0): } \\
\text { 3.1.1 Criticality Prevention System }\end{array}$} \\
\hline \multicolumn{4}{|c|}{ SE SYSTEM EQUIPMENT/COMPONENT LIST } \\
\hline $\begin{array}{l}\text { MASTER } \\
\text { COMPONENT } \\
\text { INDEX } \\
\text { NUMBER }\end{array}$ & $\begin{array}{l}\text { FUNCTIONAL } \\
\text { DESCRIPTION }\end{array}$ & $\begin{array}{l}\text { CRITICALITY } \\
\text { PREVENTION } \\
\text { SPECIFICATION } \\
\text { NUMBER }\end{array}$ & $\begin{array}{l}\text { ESSENTIAL } \\
\text { DRAWING NUMBER }\end{array}$ \\
\hline $\begin{array}{l}\text { CRDR-2ND_EAST-1 } \\
\text { CRDR-2ND_EAST-2 } \\
\text { CRDR-2ND_EAST-3 } \\
\text { CRDR-2ND_EAST-4 } \\
\text { CRDR-2ND_EAST-5 } \\
\text { CRDR-2ND_EAST-6 } \\
\text { CRDR-2ND_EAST-7 } \\
\text { CRDR-2ND_EAST-8 } \\
\text { CRDR-2ND_EAST-9 } \\
\text { CRDR-2ND_EAST-10 } \\
\end{array}$ & $\begin{array}{l}\text { CRITICALITY DRAIN 2ND EAST } \\
\text { GLOVEBOXES. FOR ASSEMBLY AND } \\
\text { INSTALLATION SEE DRAWING H-2- } \\
29941 \text { sht } 1 .\end{array}$ & $\begin{array}{l}\text { CPS-Z-165-80709 } \\
\text { CPS-Z-165-80010 } \\
\text { CSAR-80-029 }\end{array}$ & \\
\hline CRDR-10-179 & $\begin{array}{l}\text { CRITICALITY DRAIN FOR GB-10-179. } \\
\text { FOR ASSEMBLY AND INSTALLATION } \\
\text { SEE DRAWING H-2-28983 AND H-2- } \\
28985 .\end{array}$ & $\begin{array}{l}\text { CPS-L-114-00020 } \\
\text { CSAR-78-008 }\end{array}$ & \\
\hline CRDR-12-179 & $\begin{array}{l}\text { CRITICALITY DRAIN FOR GB-12-179. } \\
\text { FOR ASSEMBLY AND INSTALLATION } \\
\text { SEE DRAWING H-2-28983 AND H-2- } \\
28895 .\end{array}$ & $\begin{array}{l}\text { CPS-L-114-00010 } \\
\text { CSAR-78-008 }\end{array}$ & \\
\hline CRDR-1-188 & $\begin{array}{l}\text { CRITICALITY DRAIN FOR GB-1-188. } \\
\text { FOR ASSEMBLY AND INSTALLATION } \\
\text { SEE DRAWINGS H-2-28536 AND H-2. } \\
28551 \text { AND ECN } 621512 \text {. }\end{array}$ & $\begin{array}{l}\text { CPS-L-114-00010 } \\
\text { CPS-L-114-00050 } \\
\text { CSAR-78-008 } \\
\text { CSER-95-005, Add } 1 \\
\end{array}$ & \\
\hline CRDR-522 & $\begin{array}{l}\text { CRITICALITY DRAIN FOR GB-522. FOR } \\
\text { ASSEMBLY AND INSTALLATION SEE } \\
\text { DRAWING H-2-26802 AND H-2-26803. }\end{array}$ & $\begin{array}{l}\text { CPS-L-114-00010 } \\
\text { CSAR-78-008 }\end{array}$ & \\
\hline CRDR-4TH_COLUMN & $\begin{array}{l}\text { CRITICALITY DRAINS FOR 4TH FLOOR } \\
\text { COLUMN GLOVEBOXES. }\end{array}$ & $\begin{array}{l}\text { CPS-Z- } 165-80704 \\
\text { CPS-Z-165-80010 } \\
\text { CSAR-80-029 } \\
\text { CSAR-80-006 }\end{array}$ & \\
\hline CRDR-5TH_COLUMN & $\begin{array}{l}\text { CRITICALITY DRAINS FOR 5TH FLOOR } \\
\text { COLUMN GLOVEBOXES. }\end{array}$ & $\begin{array}{l}\text { CPS-Z-165-80705 } \\
\text { CPS-Z-165-80010 } \\
\text { CSAR-80-029 } \\
\text { CSAR-80-006 } \\
\end{array}$ & \\
\hline CRDR-6TH_COLUMN & $\begin{array}{l}\text { CRITICALITY DRAINS FOR 6TH FLOOR } \\
\text { COLUMN GLOVEBOXES. }\end{array}$ & $\begin{array}{l}\text { CPS-Z-165-80706 } \\
\text { CPS-Z-165-80010 } \\
\text { CSAR-80-029 } \\
\text { CSAR-80-006 }\end{array}$ & \\
\hline
\end{tabular}




\section{DISTRIBUTION SHEET}

\begin{tabular}{|c|c|c|c|c|c|}
\hline \multirow{2}{*}{$\begin{array}{l}\text { To } \\
\text { Distribution }\end{array}$} & \multirow{2}{*}{\multicolumn{3}{|c|}{$\begin{array}{l}\text { From } \\
\text { J. P. King }\end{array}$}} & \multicolumn{2}{|l|}{ Page 1 of 1} \\
\hline & & & & \multicolumn{2}{|l|}{ Date $7 / 26 / 00$} \\
\hline \multirow{2}{*}{\multicolumn{3}{|c|}{$\begin{array}{l}\text { Project Title/Work Order } \\
\text { Authorization Basis for PFP, FSAR/OSR }\end{array}$}} & & \multicolumn{2}{|l|}{ EDT No. N/A } \\
\hline & & & & \multicolumn{2}{|c|}{ ECN No. 659388} \\
\hline Name & MSIN & $\begin{array}{l}\text { Text } \\
\text { With All } \\
\text { Attach. }\end{array}$ & Text Only & $\begin{array}{l}\text { Attach./ } \\
\text { Appendix } \\
\text { Only }\end{array}$ & $\begin{array}{c}\text { EDT/ECN } \\
\text { Only }\end{array}$ \\
\hline
\end{tabular}

D. A. Conners

L. E. Edvalson

J. P. King

J. J. McCracken

B.S. Mo

S. E. Nunn

A. L. Ramble

R. L. Rhoten

R. G. Wilbanks

Central Files
T5-1X51 X

T5-4854 $\mathrm{X}$

T5-54 X

R3-79 X

T5-54 X

T5-1151 X

T5-54 $\mathrm{X}$

T5-04 X

T5-08 $X$

$B 1-07 \quad x$ 